\title{
Hva er en lege?
}

\author{
Stakkars pasient som skal prøve å identifisere legen blant alle de hvitkledde som vrimler \\ omkring på det store sykehuset. Man snakker med én lege, men så kommer det straks \\ en annen - og alle legene er forskjellige og sier forskjellige ting. Her er et fors $\varnothing k$ på en liten \\ opprydning for å få klarhet i hva og hvem en lege er.
}

\begin{abstract}
Den medisinske profesjonen består av temmelig ulike personligheter som arbeider på tilsvarende ulike måter. For pasienten kan dette være forvirrende, særlig i dagens medisinske verden, siden det vrimler med legespesialister rundt sykesengen. Noen er små, noen er store, enkelte er atletiske, mens andre er slappe med store mager. Dessuten finnes det mange vakre kvinner med lyst, utslått hår som er leger, andre er ikke fullt så fargerike. Alle kommer inn og presenterer seg for pasienten med et vennlig smil. Navnet blir som regel sagt i rasende fart, og det skal noe til å oppfatte navnene på så mange ulike personer som passerer forbi i løpet av ett eneste døgn.
\end{abstract}

Dette mangfoldet av leger skal også konkurrere med en økende skare av andre profesjoner innen helsevesenet. Ikke bare samhandler de andre med legene, i tillegg går de også i hvit frakk og kan forveksles med legen. Stetoskopet blir i dag brukt av både sykepleiere, jordmødre og jordfedre, det er ikke lenger noe varemerke for legen. Hvit frakk kan dessuten være antrekk for sykehusets fysioterapeut, frisør, prest, konditor og andre. Et ekstra problem er at mange ansatte innen det psykiske helsevernet går uten frakk og dermed lett kan forveksles med pasientene. Hvordan i all verden skal en pasient finne ut hvem som er legen i alt dette mylderet?

Da er det på tide å trekke frem igjen den analysen av ulike legetyper som Ingvard Wilhelmsen og Jon Geir Høyersten publiserte $\mathrm{i}$ Tidsskriftet for over to tiår siden. Begge to er noen skikkelige fargeklatter i norsk medisin, og paradoksalt nok atskiller de seg fra de klassiske legetypene.
Ingvard Wilhelmsen er psykiater, indremedisiner og ekspert på hypokondere. For å overdrive litt: Med noen få undersøkelser kan han fastslå om det foreligger en genuin hypokondri eller om det bare er noe pasienten innbiller seg, det vil si en simulert hypokondri. Dertil er han en gudbenådet underviser, foredragsholder og forfatter.

Ved siden av lang praksis innen klinisk psykiatri og rettspsykiatri har Jon Geir Høyersten supplert legeutdanningen med filosofistudier. Doktorgraden tok han på en avhandling om personlighetsforstyrrelser i de norrøne ættesagaene. Med andre ord har han ett bein i medisinernes og ett i humanistenes rekker. Da han og Wilhelmsen arbeidet sammen på daværende Psykiatrisk klinikk ved Haukeland universitetssykehus, skrev de en analyse av personlighetstyper blant legene. Ut fra denne kan man noen ganger klare å identifisere legen med rimelig god sikkerhet. En kompliserende faktor er imidlertid at legene kan klassifiseres i flere ulike personlighetstyper som går pasientene en høy gang. Det trenger vi å huske på i dagens gjennomorganiserte og strømlinjeformede helsevesen. Derfor er de to psykiaternes tankevekkende og underfundige artikkel vel verd å lese på ny - som et hyperaktuelt historisk dokument.

\section{Ole Didrik Lærum}

ole.laerum@gades.uib.no

Ole Didrik Lærum (f. 1940) er professor (adj.) ved Københavns Universitet og professor emeritus ved Universitetet i Bergen

\section{Legetyper - finnes de?}

Tidsskr Nor Lageforen $n r .30,1992 ; 112: 3874-6$

Det finnes mange forsøk på å inndele menneskene i forskjellige personlighetstyper. En av de eldste tradisjonene har i århundrer blitt muntlig overlevert i klostrene, og er først i de siste 10-15 år skrevet ned. Systemet har vært under stadig revisjon og utvikling, og blir i denne artikkelen anvendt for å analysere dagens norske legestand, skriver Ingvard Wilhelmsen \& Jon Geir Hoyersten, overleger ved Psykiatrisk klinikk,
Haukeland sykehus. Hensikten er å oppmuntre til ettertanke omkring rolle og funksjon som leger, med særlig fokus på sammenhengen mellom personlighet og yrkesliv. Emnet er etter forfatternes mening så viktig at det med fordel kunne bli gjenstand for mer seriøs forskning og utredning.

De tidligste forsøk på å fatte og kartlegge menneskets «indre krefter» og skjebne - personligheten - finner vi i den klassiske astrologi. De eldste dokumenterte eksempler skriver seg fra babylonsk-assyrisk høykultur, ca. år 600-700 f.Kr. Det dreide seg om nitide og høytidelig utarbeidede horoskoper for fyrstene og herskeren. Dette er en tradisjon som holdt seg gjennom århundrene, utover renessansen, og med så betydelige utøvere som Kepler og Tycho Brahe, Roger Bacon, vår egen kollega Paracelsus, og sogar reformasjonsfaderen Melanchton. 
Kun den katolske kirke tok avstand fra astrologien som regulær overtro. Til grunn for denne oppfatning av en korrespondanse mellom stjernehimmelens konstellasjon og personens indre liv lå en forestilling om en grunnleggende parallellitet mellom makrokosmos og mikrokosmos, en forestilling som også går igjen i den europeiske mystikks historie fra antikken av. Fra antikken (Hippokrates, Galen) finner vi også den stadig like populære humorale teori om de fire temperamenter, knyttet til balansen mellom kroppsvæskene - det sangvinske (sangvis $=$ blod), det melankolske (melaine chole $=$ sort galle), det koleriske $($ chole $=$ gul galle $)$ og det flegmatiske (flegma $=$ slim). Denne modellen, med sin firedeling og bruk av somatiske metaforer, kommer forbausende nær opp til en del nyere personlighetsteorier (Sjøbring, Jung), og er godt beskrevet i en klassisk norsk bok (1).

Det er først i vårt eget århundre at man innen medisinen og psykiatrien har begynt å studere personlighetspsykologi og personlighetsforstyrrelser systematisk. Det kan kanskje heller ikke undre oss at dette er det området innen psykiatrisk diagnostikk hvor det har vært minst konsensus innen WHOs diagnoseliste (ICD-9). Men som av og til ellers innen psykologi og psykiatri kommer ikke alltid de store nye perspektiver innenfra, fra fagets egen kjerne. Tradisjonelt har f.eks. psykosomatikk og studiet av bevissthet vært forvaltet av filosofien (f.eks. Descartes, Bergson, Husserl). Hvor utfordrende og fascinerende er det ikke så å komme over en rikt nyansert og velutviklet personlighetspsykologi som har eksistert og vært videreutviklet innenfor den europeiske klostertradisjonen fra de første århundrer (både jesuitterordenen og fransiskanerne), sannsynligvis med utgangspunkt $i$ en gammel østlig tradisjon (de muslimske mystikerne Sufiene). Systemet kalles enneagrammene, som betyr ni punkter (fig 1), og skal ha blitt utviklet som en hjelp for abbeden til å forstå og veilede den unge klosterbroder. Novisiatet kan nemlig, i likhet med legeyrket, være en ekstrem stressituasjon. Som kjent vil langvarige sterke belastninger og kriser sette den enkeltes personlighetstrekk i relieff. Denne århundregamle muntlige tradisjon er i løpet av de siste ti år blitt skrevet ned, og er således blitt tilgjengelig for et bredere publikum (2-3). Vi vil i denne artikkelen bruke enneagrammene for å beskrive ni forskjellige legetyper. Hensikten er å gi næring til ettertanke omkring vår funksjon som leger. Karaktertrekk og personlige kjennetegn representerer et kontinuum uten klare grenser, og det er heller ikke skarpe skiller mellom typene, som alle er like «gode». Der er innen hver type en indre dynamikk, og hensikten med den opprinnelige tradisjon var å peke på muligheter til vekst, her kalt «forløsning».

\section{Tre hovedgrupper}

Vi kan først grovsortere legene i tre hovedgrupper, representert ved tre forskjellige byer.

De hodestyrte trives best i Caput. Når du kommer med fly til Caput, ser du at byen er bygd ut fra en klar, logisk og funksjonell plan. Gatene er ordnet i parallelle rekker, parkene er strategisk plassert. Husene er enkle og lite prangende, og glasset i stuevinduene av en type som gjør det lett å se ut, men nesten umulig å se inn. Innbyggerne her liker bedre å beskue andre enn selv å delta. Gatene er stille og rolige, og det er gjerder rundt de fleste eiendommene. Caput er et læresenter med mange høyskoler og universiteter. Kirken heter St. Thomas.

De hjertestyrte bor og jobber i Cordis. Dette er en by bygd helt uten plan. Husene ligger tett og er plassert ut fra at de skal dekke et menneskelig behov. Overalt står det mennesker og snakker sammen, og istedenfor gjerder mellom husene er det flere stier på kryss og tvers. Ved siden av alle legene er gatene fulle av sykepleiere og sosialarbeidere på vei til eller fra et av de mange sykehus eller diakoniinstitusjoner. Bybildet er hektisk, og her finnes en rekke tilbud innen veldedige foretak (Lions, Rotary o.1.), konserter, dansearrangementer og slankeklubber. Kirken heter St. Martha.

Den siste gruppen er de magestyrte som har samlet seg i Humus. Innbyggerne her er opptatt av rettferdighet og miljøspørsmål. Menneskene i gatene er spontane og handlingsrettede, og hevder sin mening uten omsvøp. Byen har mange museer, men også sportsanlegg. Innbyggerne har like gjerne en grønnsakhage som blomsterbed, og klesdrakten er usofistikert. Kirken heter St. Peter.

\section{Ni legetyper}

\section{De hjertestyrte}

Type 2. Selvbilde: «Jeg hjelper.» Denne legetypen stiller seg til andres rådighet, og bygger sin identitet på å være til hjelp. De er nær hos den som lider og har vondt. En skyggeside kan være en sterk trang til å få bekreftelse, og legen sier da med hele sitt vesen: Ha behov for meg! Den uforløste toer har problemer med å si nei, og føler seg ofte utnyttet og misbrukt. En fare blir da hjelpersyndromet utbrenthet, med fare for å utvikle Messias-kompleks eller martyrfantasier. Denne legetypen kan trenge hjelp til å ta egne behov på alvor, og må øve seg på å sette grenser, og kanskje også å gjøre noe for andre som ikke «lønner seg». Dersom denne legetypen lærer seg til å leve med sin emosjonelle hypersensibilitet på en sunn måte, kan de som ingen andre leve opp til vårt ideal om å «lindre og trøste». Dette er en typisk kliniker som sjelden ender opp blant reagensrør eller papirstabler.

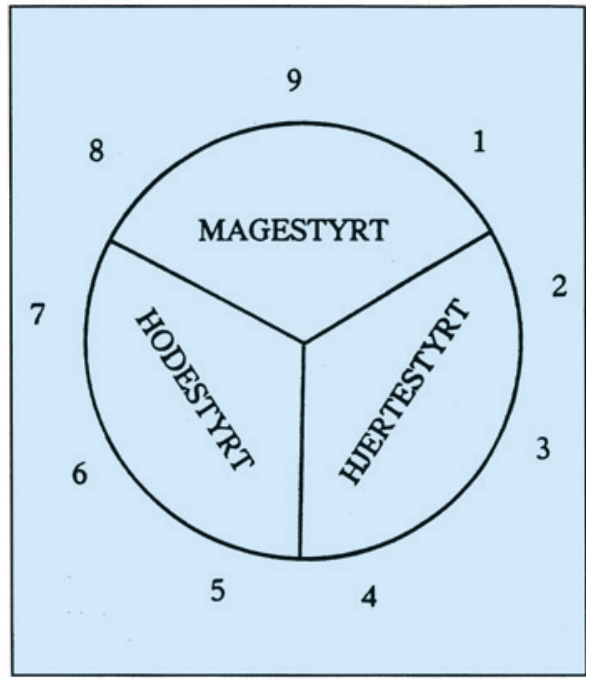

Figur 1 Plassering av de ni legetyper i enneagrammet

Type 3. Selvbilde: «Jeg lykkes.» Denne legetypen har en tillitvekkende og sikker utstråling, leser sine oppgaver effektivt og kompetent, og legger vekt på karriere og status. De spør ikke som toeren: Er jeg elsket? Men -: Har jeg suksess? De kan arbeide hardt og gi all sin energi til jobben, som gjerne kan være «prosjektpreget». En skyggeside kan være liten selvinnsikt og en utpreget evne til å bære forskjellige «masker». De trenger ofte mye ros, og har ingen lengsel etter dybde. Den uforløste varianten hater nederlag som pesten, og omgås derfor sannheten litt lemfeldig. Et nederlag omskrives gjerne til en delseier (kateteret var på riktig plass i høyre atrium) selv om det egentlig var et tap (pasienten døde under en invasiv prosedyre). Denne legetypen kan ha nytte av å gå i dybden, og må lære egne følelser bedre å kjenne. Man må ta inn også sine nederlag, og gjerne påta seg oppgaver som krever tålmodig småarbeid og hvor det ikke finnes raske resultater. Treeren kan da som få andre være gode veiledere som hjelper og motiverer andre og avdekker deres potensialer. Denne legetypen stikker hvert år av med mange NAVF-stipendier!

Type 4. Selvbilde: «Jeg er annerledes.» Denne legetypen skiller seg en del ut fra andre, bl.a. i klesdrakten (liker ikke å gå i hvit frakk). De har ofte kunstneriske gaver, er interessert i dans, musikk, maleri, teater o.l., og briljerer med stil og klasse. De hater det alminnelige og gjennomsnittlige, og legger gjerne stor vekt på ekthet. En del leger av denne typen sliter med melankoli, men da i form av en «søt tristhet», man må liksom være litt deprimert for å kunne være virkelig lykkelig. Allerede ved 25-årsalderen har denne legetypen gjennomlevd alt fra agoni til ekstase, og kjenner forskjellige følelsesnyanser og sjelens avgrunner 




Figur 2 De ni legetypene. Illustrasjon Ragnhild Gjerstad

bedre enn de fleste. Når fireren får disiplinert sitt følelsesliv, kan de på en spesiell måte hjelpe andre som er i dyp, sjelelig nød. Dersom de legger vekk sin snobbethet og fordekte elitebevissthet, kan de hjelpe andre gjennom å utvide vårt tradisjonelle, snevre syn på verden og legerollen.

\section{De hodestyrte}

Type 5. Selvbilde: «Jeg gjennomskuer.» Denne legetypens spesielle begavelse er å kunne være objektiv og beholde roen $i$ alle situasjoner. Man preges av en sterk evne til observasjon, og man er heller tilskuer enn deltaker. Femmeren har en tendens til å hamstre viten, og utdanner seg stadig videre. Det kan være vanskelig for femmeren å innse at styrken (objektiviteten) også kan være den store svakheten, særlig dersom man alltid må distansere seg. Dette kan i kollegafellesskapet føre til at man som overlege alltid «har sett alt tidligere», og man lar seg da i liten grad rive med av assistentlegens begeistring. Denne legetypen utfordres til engasjement og handling, ikke prefleksjon - tenke istedenfor å handle, men refleksjon - den etterfølgende tankemessige bearbeiding av opplevd liv. Den forløste femmer er den virkelig vise legen som kan hjelpe andre med sine systemer og klokskap.

Type 6. Selvbilde: «Jeg gjør min plikt.» Leger av denne typen er ofte svært lojale mot lauget, og finner gjerne trygghet $i$ en fasttømret legerolle. De kan ha en tendens til katastrofetenkning, og ser da fare hvor fare egentlig ikke finnes. De vil sjelden ta sjanser, og kan ha en litt lammende «angst for å svikte». Man kan ha en forkjærlighet for lukkede, ortodokse behandlingsopplegg, og man har en velutviklet skepsis. Hvis du vil rose en sekser, må du blande det positive med et minimum av konstruktiv kritikk, ellers vil de bli mistenksomme. Når denne legetypen klarer å løsrive seg fra de menneskelige autoriteter og selv tar ansvar, vil de på en egen måte kunne fungere godt i vanskelige situasjoner. Dette har sin bakgrunn i at man gjennom livet har lært å omgås angst, og dette gir muligheter for spesiell innlevelse og forståelse for andre. Dersom du forbereder et prosjekt, kan det være lurt å få kommentarer fra en sekser, som lett vil se hva som ev. kan ga galt.

Type 7. Selvbilde: «Jeg er lykkelig.» Denne legetypen utstråler optimisme og glede, og er fulle av fremtids- og ferieplaner. Som leger er de oftere generalister enn spesialister. De er gjerne antiautoritære, og det er smertefullt når frihet $\mathrm{og}$ muligheter begrenses. Syveren kan leve i årevis uten å se livets mørke sider, og lever gjerne etter mottoet: Heller rik og frisk enn fattig og syk. Denne legetypen kalles til realisme, og når den falske idealismen viker til side, kan man lettere se forskjellen på overfladisk optimisme og dypt begrunnet håp. Den forløste syver vil som få andre kunne støtte pasienter og kolleger med en nøktern glede, og er nærmest den ideelle visevert ved jubileer og fester.

\section{De magestyrte}

Type 8. Selvbilde: «Jeg er sterk.» Dette er den sterke og mektige, som hater uklare budskap. I en faglig konflikt spør åtteren (pga. tendens til alt-eller-intet-tenkning): Er du for eller imot? Det er lett å engasjere seg med stor energi, men vanskelig å innrømme feil, da dette kan bli oppfattet som svakhet. Åtteren søker konflikt og har ikke problemer med å være uenig med deg, men forstår ikke så lett at egen styrke kan vekke angst hos andre. Dette er leger som nyter å ha makt, og ofte har behov for å kontrollere; trenger mye rom alene, og liker gjerne utfordringer alene i naturen (Marlboro-man). Åtteren vekker reaksjoner, og enten man vil eller ikke så reagerer man på dem. Kanskje vil åttere ha en tendens til å velge kirurgien som fag? (opererer mens man venter på prøveresultatene). En svakhet er hangen til retthaveri, og tendens til å ta makten $\mathrm{i}$ egne hender. Den forløste åtter som f.eks. har gått til en toerkollega og lært barmhjertighet, vil kunne være en velsignelse med sin livskraft, store arbeidskapasitet og villighet til å innta viktige posisjoner.

Type 9. Selvbilde: «Jeg er tilfreds.» Dette er den rolige, fredelige legetypen som kan virke litt «usynlig», og som lett aksepterer andre. Man føler seg forstått og vel mottatt av en slik kollega. De er ofte generalister som kan litt av alt, siden man ofte ikke gidder eller har mot til å utbre sitt talent for andre. De svømmer gjerne med strømmen, og velger derved minste motstands vei. Problemet med nierne kan være å få dem i gang, få dem til å «reise seg» og ta ansvar (ikke si: Hvorfor stå når jeg kan sitte? eller: Hvorfor sitte når jeg kan ligge?) Nieren unngår konflikter, og kan provosere med sin passivitet. Man bør oppfordre slike kolleger til å fullføre et påbegynt prosjekt, eller på annen måte få dem til å handle. Nierne er utmerkede meglere og formidlere, og det vil aldri være noe problem om en nier ble generalsekretær i Legeforeningen eller endog helsedirektør. De kunne redde verden, men problemet er at de ofte er de siste som ville utvikle nok ærgjerrighet eller energi til å komme i så innflytelsesrike posisjoner.

Type én. Selvbilde: «Jeg har rett.» Dette er idealister som gjerne påtar seg lederansvar, og som aktiveres når de oppdager at noe er feil eller urettferdig. De er utpreget ansvarsbevisste, og tillater seg ingen glede eller atspredelse i det godes tjeneste. Det er vanskelig å se bjelken i eget øye, og enerne er av natur asketer og puritanere. Denne legetypen må lære seg til å omgås sin aggresjon, som er den egentlige drivkraft bak all innsatsen. Det kan være forløsende å le litt av seg selv, og f.eks. lære å leke av syveren. Den forløste ener vil ha et sterkt bidrag til fellesskapet med sin kritiske potens og drømmen om det fullkomne.

\section{Avslutning}

Når man står overfor en personlighetstypologi kan det være nyttig å huske på at rene legetyper ikke finnes i virkeligheten. Der 
er vi alle individuelle og en blanding av mange egenskaper. Det er likevel ting som tyder på at vi alle har et «tyngdepunkt» som til en viss grad lar seg beskrive i generelle termer. Det evig uutgrunnelige ved disse «systemene» er vanskeligheten med å rubrisere seg selv i en eller annen kategori, mens de fleste av våre kolleger såre lett lar seg diagnostisere. Derfor til slutt en påminnelse om at slike systemer egner seg best til «invortes bruk», som et speil i vår selvrefleksjon i forhold til egen rolle og funksjon.

\section{Ingvard Wilhelmsen Jon Geir Høyersten \\ Psykiatrisk klinikk Haukeland sykehus 5021 Bergen}

\section{Litteratur}

1. Hallesby 0. Temperamenteme i kristelig lys. Oslo: Lutherstiftelsen, 1927.

2. Rohr R, Ebert A. Discovering the enneagram. An ancient tool for a new spiritual journey. New York: Crossroad, 1991.

3. Wagner JP. A descriptive, reliability, and validity study of the enneagram personality typology. Doktoravhandling. Chicago: Loyola University of Chicago, 1981. 